\title{
Practical Image Measurement of Crack Width for Real Concrete Structure
}

\author{
Tomoyuki YamaguchiＮon-member（Waseda University, yamaguchi@akane.waseda.jp) \\ Shuji Hashimoto Member (Waseda University, shuji@waseda.jp)
}

Keywords : Crack width, Sub-pixel accuracy, Image measurement, Crack scale, Practical use

Crack width is an important data in the inspection and diagnosis for the safety management of concrete structures. Usually the crack width measurement is done manually by specialists using crack scale. However, the method does not only require time and effort but also lacks objectivity for quantitative analysis. Therefore, the importance of image processing for visual inspection has been increasing in civil and construction engineering. Recently, many methods for the crack width measurement have been proposed. We have also tried to measure crack width utilizing image processing. However, these methods concentrated only on the application to test specimens whose size is known. Therefore, these researches did not discuss about practical use.

In this paper, we propose an improved image measurement method of crack width for the application to real concrete structures whose size is unknown, and clarify the efficient condition of our method for the practical use. The proposed method consists of 7 steps; which are image acquisition, crack detection, dilation of crack region, extraction of crack brightness, thinning processing, labeling processing and crack measurement. In the step of crack detection, we uses our method, which has already applied to detect cracks with fine accuracy on real concrete surfaces. To measure the exact size of crack width, it is necessary to know correct size of the object like test specimens. However, it is difficult to know the size of the real object in advance when we consider practical use. Therefore, in our method, we attached the crack scale on the concrete surface in the step of image acquisition as shown in Figure 1(a), because the crack scale has already been written the size per scale on the crack scale as shown in Figure 1(b). For the measurement of correct crack width, we use the brightness of width per crack scale. Then, we calculate the feature value $W$ as follows,

$$
W_{i}=\operatorname{med}_{j \in R_{i}}\left(S_{j}(x, y)\right)
$$

where $i$ is the number of label, $R_{i}$ is the set of pixels in the label, $j$ is the suffix of $R_{i}, S_{j}(x, y)$ is the total brightness calculated in the step of thinning processing, and med() is median function.

The calibration line is produced by the feature value $W$ and width per scale as shown in Figure 2. In our method, the calibration line is used to calculate the crack width for the exact size.

In the real world, the lighting condition is different in various environments. Since the proposed method uses the brightness

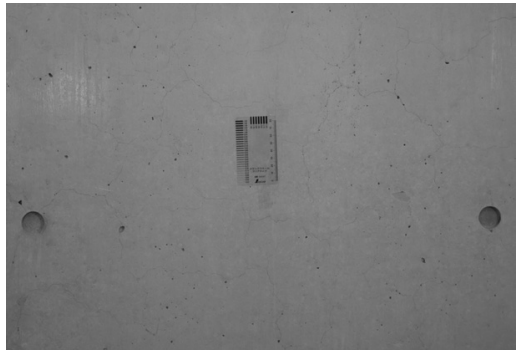

(a) Crack scale on a concrete surface

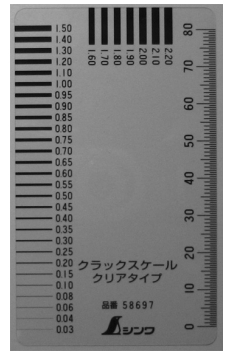

(b) Crack scale
Fig. 1. Setting crack scale

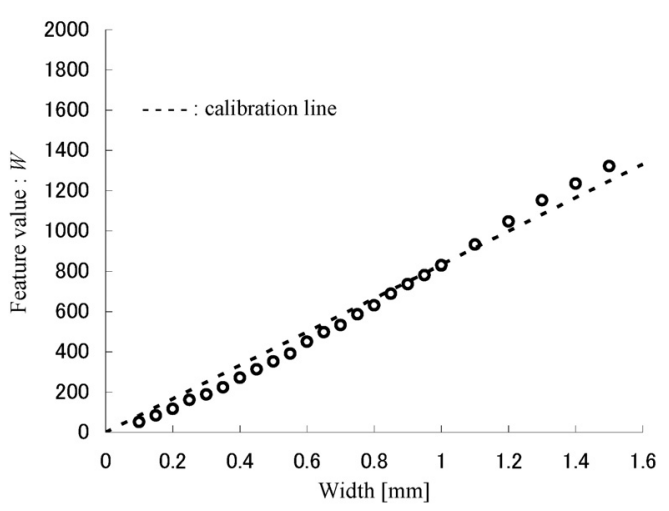

Fig. 2. Calibration line

information, the influence of the lighting condition is not avoided. Therefore, we conducted an experiment with images including two crack scales in order to evaluate the influence of the different lighting conditions to our method. In this experiment, our method could measure the width with fine accuracy, if the width is thinner than about $0.5 \mathrm{~mm}$. We consider that our method can be applied to measure the crack width, in case that the width of cracks are thinner than $0.5 \mathrm{~mm}$ on the real concrete surface.

Finally, the validity of the proposed method are investigated through experiments with images of a real concrete surface whose size is unknown; including the width from $0.06 \mathrm{~mm}$ to $0.30 \mathrm{~mm}$. In the result of this experiment, the proposed method could measure the crack width with sub-pixel order accuracy : $0.05 \mathrm{~mm}$, even if the condition of lighting is different. 


\title{
論 文
}

既設コンクリート構造物におけるひび割れ幅の実画像計測

非会員 山口 友之* 正員橋本 周司**

\author{
Practical Image Measurement of Crack Width for Real Concrete Structure \\ Tomoyuki Yamaguchi*, Non-member, Shuji Hashimoto**, Member
}

\begin{abstract}
Crack width is an important data in the inspection and diagnosis for the safety management of concrete structures. Usually the crack width measurement is done manually by specialists using crack scale. However, it takes a long time and lacks the objectivity for quantitative analysis. Therefore, the importance of image processing for visual inspection has been increasing in civil and construction engineering. Recently, many methods for the crack width measurement have been proposed. We have already tried to measure crack width utilizing image processing. However, these methods concentrated only on the application to test specimens. In this paper, we proposes an improved image measurement method of crack width for the application to real concrete structures. Our method attached crack scale on the concrete surface in the image acquisition. Crack width is measured by the brightness of crack scale areas on the image with sub-pixel order accuracy. In the real world, the lighting condition is different in various environments. For its difference, this paper clarifies the efficient condition of our method for the practical use. The validity of the proposed technique is investigated through experiments with images of a real concrete surface.
\end{abstract}

キーワード : ひび割れ幅, サブピクセル精度, 画像計測, クラックスケール, 実利用

Keywords : Crack width, Sub-pixel accuracy, Image measurement, Crack scale, Practical use

\section{1. 緒 言}

近年，土木・建築分野においても，単純なスクラップア ンドビルドの時代から，環境的な視野に立ち，既設の構築 物をいかに永く供用していくかということが重視される時 代になりつつある。一般的にコンクリートは耐久性の高い 材料であるが, コンクリート構造物の置かれる環境によっ ては, コンクリートの性能が徐々に低下し, その耐久性に 影響が生じる場合がある。コンクリート構造物の代表的な 劣化機構としては，中性化・塩害・凍害・アルカリ骨材反 応・化学的浸食等がある。これらが原因となり，コンクリ 一トにひび割れ・内部鉄筋腐食・剥離・変色・部材耐力低 下などの劣化現象が生じる。一般建築物及び土木構造物の 維持管理においては, 構造物に生じた劣化現象から劣化機 構を特定し, 劣化原因を明確にして, 評価・判定した上で, その対策（補修・補強）の要否を判断するという手順がと られる。このような劣化診断のうち目視によるコンクリー ト表面に生じたひび割れの検査は，コンクリート構造物の

\footnotetext{
* 早稲田大学大学院理工学研究科物理学及応用物理学専攻 干169-8555 東京都新宿区大久保 3-4-1 Major in Pure and Applied Physics, Waseda University 3-4-1 okubo shinjuku, tokyo 169-8555

** 早稲田大学理工学部応用物理学科 干169-8555 東京都新宿区大久保 3-4-1 Dept. of Applied Physics, Waseda University 3-4-1 okubo shinjuku, tokyo 169-8555
}

内部損傷状況を調べる等の詳細な調査の必要性を判断する ための重要な情報を与える資料となる ${ }^{(1)}$ 。

従来のひび割れの検査では，専門技術者の目視によりク ラックスケールやルーペを用いて，ひび割れの幅や長さを 計測している。特にひび割れ幅の測定は, 構造物の耐久性 や劣化原因を推定する上で, 極めて重要な測定指標とされ る(2)。しかしながら, 長大な構造物のように検査範囲が膨大 となる場合や直接の目視検査が困難であり, 従来の目視検 查に代わる効率的かつ経済的な方法の候補として, 計算機 による画像処理手法を用いた画像検査が注目されている。

コンクリートの画像検査に関する従来の研究では，特に， 画像中からひび割れを自動検出する報告(3) (7)が多く見られ る。筆者らもひび割れの連結性に注目し，パーコレーショ ンモデルを用いたひび割れ検出手法を提案し, 実構造物の コンクリート表面像に適用し有効な成果を得た ${ }^{(8)(9)}$ 。一方, ひび割れ幅については, サブピクセルオーダの計測が要求 される。Dare ら ${ }^{(10)}$ は, 画像が離散した画素の配列であるこ とに注目し，検出したひび割れをバイリニア補間し，サブ ピクセル計測を行っているが，計測単位は画素単位である。 Chen ら ${ }^{(11)(12)}$ は Dare $~^{(10)}$ の手法を改良し, DOG フィルタと 2 次曲線補間の適用によりサブピクセル計測を行った。この 手法では撮影対象を大きさが既知である試験片とし, 試験 片の大きさと画像サイズからひび割れ幅の実寸変換を行っ ている。ここで試験片とは, 鉄筋とコンクリートで形成さ 
れる直方体の塊であり，荷重や振動試験に用いられるもの である。試験片に対するひび割れ幅の計測は，主として荷 重や振動に対する耐久性の評価に用いられる。Sohn ら ${ }^{(13)} も$ 同様に実寸でひび割れ幅の計測結果を示しているが，撮影 対象が試験片である。これらの報告に共通して言えること は，撮影対象が試験片であり，対象の大きさが既知である ため, 画像サイズと対応させることで実寸計測が行えてい る。従って, 対象が試験片でない場合には, 実寸計測を適 用することが困難である。

また，その他の報告としては，佐野ら ${ }^{(14)}$ はコンクリート 表面に 2 つのマーカを固定して設置することにより，マー カ間のひび割れ幅を画像を用いて実寸計測している。しか し, マーカ間のひび割れ 1 本のみが計測対象となるため, 計測範囲が限定されてしまい，非効率である。Schutter ${ }^{(15)}$ は ビデオマイクロスコープを用いてひび割れ幅の実寸計測を 行っているが, 計測手法は明確に示されていなく, 機器が 特殊であり，計測範囲も狭い。

筆者らは目視検査において, 人間がクラックスケールと いう基準サンプルを利用してひび割れ幅の計測を行うこと に注目し，クラックスケールを画像中に写りこませ，クラ ックスケールの輝度情報を基に, 画像内のひび割れ幅を実 寸計測する手法を提案した ${ }^{(16)}$ 。しかし, 計測対象が試験片 であり，実構造物への検討は行われていない。また，画面 内でのコントラストの変化や照明ムラの影響を抑えるた め, 試験片を撮影した画像と白板を撮影した画像の差分を とることで，シェーディング補正を行っているが，実構造 物に適用する場合には現実的ではない。さらに，ひび割れ は画像上ではコンクリートの亀裂の影であるため, シェー ディング補正を行ったとしても輝度情報を用いる場合に は，照明による影響はさけられない。従って，照明による 影響を評価した上で, 実利用に関して検討を行う必要があ る。

そこで，本論文では，大きさが未知である実構造物のコ ンクリート表面を撮影対象としたひび割れ幅の実寸計測手 法を提案し, 提案手法の実利用の条件を明確にする。

まず，ひび割れ検出では，既に実構造物のコンクリート 表面像に適用し良い結果を得ている筆者らの手法 ${ }^{(8)}$ を用い る。次に, 照明ムラに対しては, ひび割れ検出を行った 2 值画像と原画像を用いて線形補間を行うことにより，背景 画像（白板を撮影した画像に相当する）を作成する。そし て, 背景画像と原画像の差分をとり, シェーディング補正 を行う。ひび割れ幅の実寸計測では，筆者らが既にクラッ クスケールを用いて試験片画像に適用した手法(16)を基に改 良を加える。従来手法ではクラックスケールに記載された 面積の輝度情報を用いて実寸変換を行っていた。面積を用 いる場合には，長さに関する基準值が必要となる。クラッ クスケールの各目盛りの長さは理論上は同じである。しか し, 画像処理を用いて 2 值化した後の画像上では, 量子化 誤差や 2 值化の閾值によって, 全ての目盛りを同じ長さで 抽出することは困難である。従って, 処理が複雑になり長

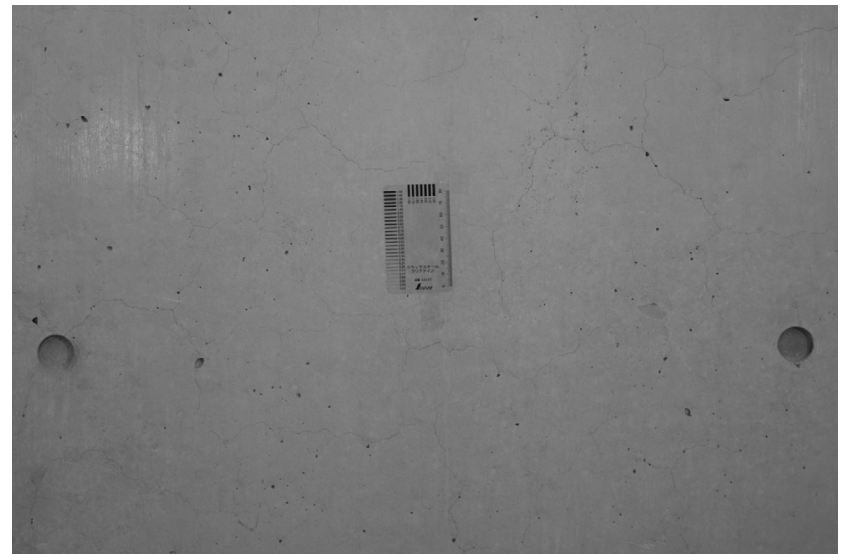

(a) Crack scale on a concrete surface

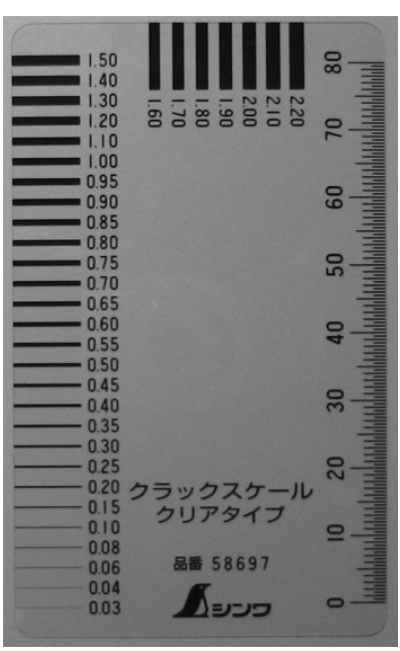

(b) Crack scale

Fig. 1. Setting crack scale.

さの規格化による誤差も増える。そこで，本研究では，ク ラックスケールの幅の輝度情報を用いて画素単位から実寸 単位への変換処理を行う。さらに, 提案手法も輝度情報を 用いるため, 提案手法に対する照明による影響を評価し, 実利用でも用いることができる条件を考察する。実験では, 既設コンクリート構造物の壁面像を用いて, ひび割れ幅の 実寸計測を行い，提案手法の有効性を検討する。

本論文は全 7 章で構成されている。2 章では本研究で用い るクラックスケールの説明とひび割れ幅について述べる。3 章ではひび割れ幅計測の流れについて述べる。4 章ではひび 割れ幅を実寸で計測を行う具体的な手法について述べる。5 章では, 提案手法の有効性の検討と, 照明条件の影響を評 価する。6 章では, 実際の既設コンクリート構造物の壁面を 撮影した画像を用いて，ひび割れ幅の実寸計測実験を行う。 最後に 7 章で結言を述べる。

\section{2. クラックスケールとひび割れ}

本章では, クラックスケールを説明し，本論文で言うひ び割れとひび割れ幅の明確な定義を行う。

〈2·1〉 クラックスケールとは 本手法では, 既設構 
造物のコンクリート表面を撮影する際に, 図 1 に示すよう な「クラックスケール」を画像中に写りこませる。クラッ クスケールには，その幅の值が 0.03 [mm $~ 2.20[\mathrm{~mm}]$ (ただ し本研究では, $0.10[\mathrm{~mm}] \sim 1.50[\mathrm{~mm}]$ を対象とする）の範囲 で正確に記載されている。図2(a)に示すように, 本来の用途 ではクラックスケールの各目盛りをひび割れに当てること により，ひび割れ幅を目視計測する。本手法では，この目 盛り領域が，ひび割れと同様に直線的な特徴を持ち，かつ 黒色であることを利用し，クラックスケールを擬似ひび割 れとして画像計測の基準に用いる。

〈2·2〉ひび割れとは 本論文で言う画像中のひび割 れとは, 図 2(c)に示すようなコンクリート表面の亀裂部分の 影のことを指す。図 2(c)の長方形内にあるようなひび割れと 類似した輝度值を持つ部分は亀裂形状ではないためノイズ とし,ひび割れとはしない。ただし, 図2(c)の破線の円で示 されるコンクリートの気泡とひび割れが連結する場合は, 気泡部分もひび割れとする。また, 図 2(c)における破線三角 はひび割れの分岐点を示し, 太線三角はひび割れが途切れ る点（画像端部でひび割れが途切れる場合を含む）を示す。 ひび割れ一つの長さは，ひび割れが途切れる点（又は分岐 点）から, 別の途切れる点（又は別の分岐点）までとする。 また, 画像中のひび割れ幅とは, ひび割れが伸びる方向と 垂直な方向のひび割れの長さとする。一つのひび割れの幅 を計測する場合には，ひび割れの位置毎にひび割れ幅を算 出し, その中央值をひび割れの幅とする。提案手法では, 画像中でクラックスケールの幅の輝度情報とひび割れの輝 度情報を比較することで，ひび割れ幅を実寸で計測してい る。また, 図2(b)はひび割れ部の拡大図である。本手法では, 画素の輝度值を用いてサブピクセル精度の計測を行う。

\section{3.ひび割れ幅計測の流れ}

本章では，コンクリート表面を撮影した画像に含まれる ひび割れの幅計測の流れについて述べる。図 3 に提案手法 の流れを示す。

\section{(1) 画像獲得}

コンクリート表面の画像を獲得するには, 高解像度 CMOS デジタルカメラ（CANON 製：EOS-1Ds）を用いる。 獲得可能な画像サイズは 4064 x 2704 [pixels]であり, 256 階 調のグレースケール画像を用いる。ここで, 画像中の座標 を $(x, y)$ とし, 座標 $(x, y)$ の輝度值を $I(x, y):(0 \leq I(x, y) \leq 255)$ と 表現する。撮影の際には, コンクリート表面上にクラック スケールを配置し, 画像中に写りこませるようにする。ま た, カメラに水準器を搭載し, 壁面とカメラを正対して撮 影する。本研究で扱う撮影対象は, 試験片と異なり大きさ が明確でないため, 1 画素に相当する実寸の長さを正確には 計測することはできない。

\section{(2) ひび割れ検出}

ひび割れを計測するためには，獲得した濃淡画像の中か らひび割れのみを検出する必要がある。そこで, 本論では, ひび割れ検出を行う手法として, 筆者らの提案したパーコ

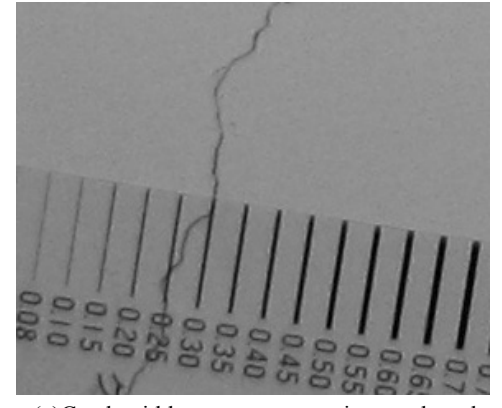

(a)Crack width measurement using crack scale

$\triangle$

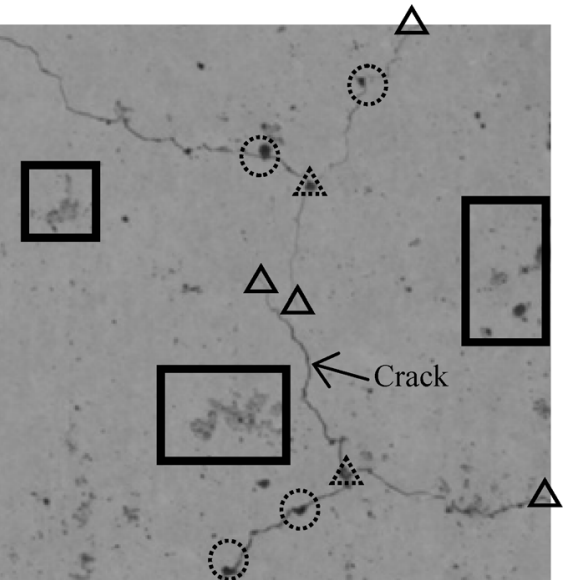

(c) Cracks and noise

Fig. 2. Definition of cracks and crack width.

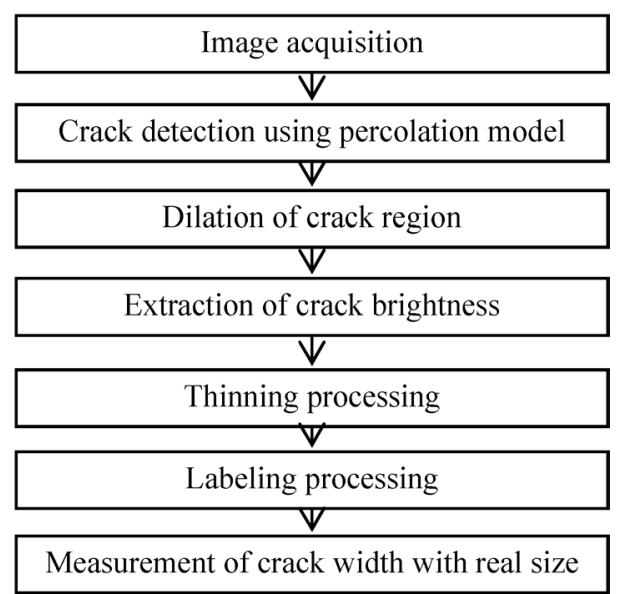

Fig. 3. Flowchart of proposed method.

レーションモデルに基づくひび割れ検出手法 ${ }^{(8)}$ を適用する。 ここで, パーコレーション(17)とは, 浸透現象に対する物理 モデルであり, 物質中を電流が流れる現象, 岩石中に液体 が浸透する現象, 森林火災や伝染病の伝播現象等の様々な 自然現象や物理現象の記述に有効とされている。

パーコレーションモデルによる画像処理は, 画像の画素 毎に行う局所処理の一手法である。この手法の手順は, ま ず，画像の濃度に基づいたパーコレーション処理を用いて 浸透領域を形成する。次に, 形成した浸透領域の特徵量を 抽出することによって, 局所領域の中心画素の特徵を評価 する。図 4 にパーコレーションの処理で形成される浸透領 域の例を示す。図 4(b)のようにパーコレーションの出発点で 
ある注目画素がひび割れである場合には，ひび割れに沿っ た領域を形成する。しかし，図4(a)のように注目画素が背景 である場合は, 全方向に広がった領域を形成する。したが って, この領域形状の違いにより, 注目画素がひび割れか 否かを評価する。評価に用いる特徴量として，浸透領域の 円形度(非直線度)を示す特徵量 $F$ を算出する。

$$
\begin{aligned}
& F=\frac{4 \cdot C_{\text {count }}}{\pi \cdot C_{\max }^{2}} \\
& \text { ここで， } C_{\text {count }} \text { は浸透領域の総画素数であり， } C_{\text {max }} \\
& \text { は浸透領域の最大長さである。特徵量 } F \text { は } 0 \text { から } 1 \\
& \text { の範囲になる。 }
\end{aligned}
$$

例えば, 図 4(a)の場合には, 浸透領域が円形状であるため, $F$ は 1 に近い值となる。一方, 図 4(b)の場合には, 浸透領域 が直線形状のため, $F$ は 0 に近い值となる。従って, ひび割 れは直線的であると考え, $F$ を用いることで, 注目画素がひ び割れであるか否かを評価できる。また, 出力画像では, 処理後と同位置座標の輝度值 $I(x, y)$ を $F \times 255$ の数值で置き 換える。最後に, 全ての画素に対して上述の処理を終了し た後, 閾值処理を行い, ひび割れを黒色とした 2 值画像を 生成する。

\section{(3) ひび割れ領域の拡張}

図 5(a)は擬似ひび割れであるクラックスケールの一部を 拡大した原画像である。図 5(a)に対して, ひび割れ検出処理 を行うと図 5(b) となる。ここで, 図 5(a)と(b)を比較すると, ひび割れ検出による 2 值化処理では, 画素精度の検出であ るため, サブピクセルの情報が欠けている。この理由とし ては, 明らかにひび割れと判断できる画素のみ，2 值化処理 で検出し，ひび割れ周辺の曖昧な輝度值を持つ画素は検出 されないためである。従って，ひび割れ幅を高精度に計測 する場合には, この曖昧な画素を用いたサブピクセル情報 が必要となる。そこで, 図 5(c)に示すように, 2 值化処理後 に膨張処理を 1 回行い, ひび割れ領域を拡張する。これに より, 図 5(d)に示すように, おおよそのひび割れ領域を補う ことができる。

\section{（4）ひび割れの輝度情報の抽出}

次に, コントラストの差や照明ムラの影響を抑えるため, 背景画像を作成し, 原画像と背景画像の差分処理によるシ ェーディング補正を行い，ひび割れ領域に相当する画素の 輝度情報の抽出処理を行う。そこで, 図 5(a)の原画像と図 $5(\mathrm{c})$ の膨張処理後の 2 值画像を用いて線形補間を行い, 図 6(a)に示すようなひび割れを含まない背景画像を作成する。

以下に線形補間の手順を述べる。

まず, 膨張処理後の画像を画像 $D$ とし, その輝度值を $D(x$, y)として以下のように表す。

$$
D(x, y)=\left\{\begin{array}{cc}
0 & \text { if crack } \\
255 & \text { if background }
\end{array}\right.
$$

次に, 画像 $D$ に対して収縮処理を施す。収縮処理の過程 において, 収縮対象となる画像 $D$ の画素座標 $\left(x_{e}, y_{e}\right)$ の 8 近傍 の座標 $\left(x_{i}, y_{j}\right)$ を考え, 原画像の輝度值 $I\left(x_{e}, y_{e}\right)$ を以下のように

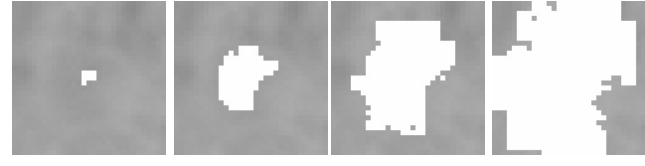

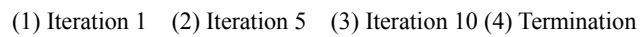
(a) Background

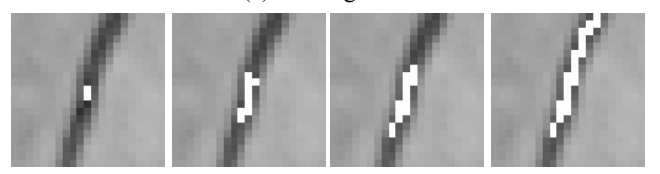

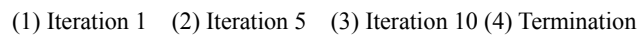
(b) Crack

Fig. 4. Example of Percolation Process.

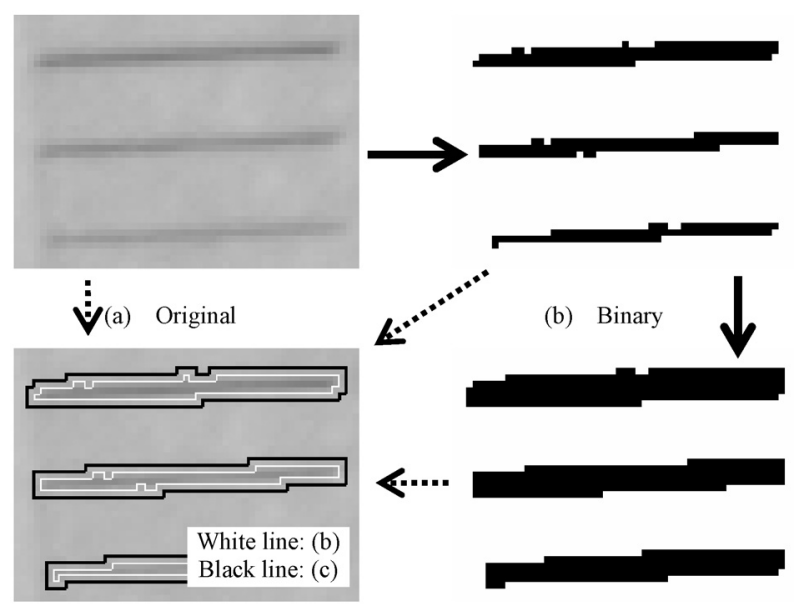

(d) Detail

(c) Dilation

Fig. 5. Setting crack area.

算出する。

$$
\begin{aligned}
& c(i, j)= \begin{cases}1 & \text { if } D\left(x_{i}, y_{j}\right)=255 \\
0 & \text { if otherwise }\end{cases} \\
& h(i, j)=\left\{\begin{array}{cc}
I\left(x_{i}, y_{j}\right) & \text { if } D\left(x_{i}, y_{j}\right)=255 \\
0 & \text { if otherwise }
\end{array}\right. \\
& I\left(x_{e}, y_{e}\right)=\frac{\sum_{i} \sum_{j} h(i, j)}{\sum_{i} \sum_{j} c(i, j)} \\
& \text { ここで， } i, j \text { は添え字とし },(i, j)=0 \sim 2 \text { とする。 }
\end{aligned}
$$

以上の算出処理を収縮処理が終了するまで行うことによ り, 背景画像が作成できる。最後に, 図 5(a) と図 6(a) との差 分処理を行い, 図 6(b)に示すようなシェーディング補正後の ひび割れの輝度值を抽出した濃淡画像を生成する。ここで, 生成された画像の輝度值 $I(x, y)$ は以下の関係式になる。

$$
I(x, y)=\left\{\begin{array}{cc}
k & \text { if crack } \\
255 & \text { if background }
\end{array}\right.
$$

ここで， $x, y$ は画像の座標值， $k$ は $0 \sim 254$ の輝度 值である。 


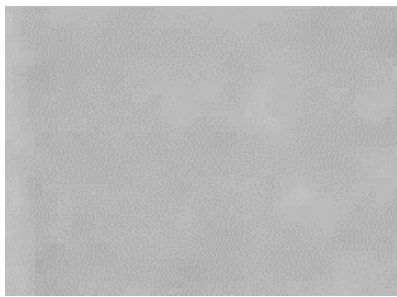

(a) Background image

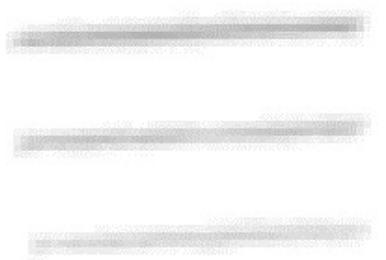

(b) Difference of background
Fig. 6. Extraction of crack brightness.

\section{(5) 細線化処理}

生成された濃淡画像に対して, 細線化処理 ${ }^{(18)}$ 施し，ひ び割れの骨格画素を生成する。本論文で言う骨格画素とは, 細線化処理 後の画素を指す。ただし, 細線化を適用する 対象は濃淡画像であるが，(6)式より，ひび割れと背景は既 に分離できているため, 背景とひび割れの 2 值画像として 処理を施す。また提案手法では, 細線化処理の際に, ひび 割れ幅を算出する一部の処理を行う(詳細は 4 章で述べる)。

\section{（6）ラベリング処理}

ひび割れには分岐する場合があるため, 細線化処理後の 画像に対して，分岐点を基準にひび割れを分割する。分岐 点の導出には, $3 \times 3$ のウィンドウ内に 4 [pixel]以上の黒画素 が存在する場合，その中心画素を分岐点とする。そして， 分割後の画像に対して, ラベリング処理 ${ }^{(19)}$ を行う。従って, ひび割れの骨格画素同士が連結しているものが同じラベル 番号で表される。

\section{(7) ひび割れ幅の実寸計測}

提案手法では，ひび割れ幅を実寸で計測するために，ク ラックスケールの幅の輝度情報を用いて，ラベル毎にひび 割れ幅の計測を行う。ただし，ラベリング処理までの過程 は, 自動的に行うが, クラックスケールの部分は, 画像上 でユーザが手動で ROI(Region of Interest)を設定し, ひび割れ 幅の計測処理を行う。

\section{4. 画素単位から実寸単位への変換}

本章では，クラックスケールを用いてひび割れ幅を実寸 で計測する手法について述べる。

〈4·1〉ひび割れ幅の算出提案手法では, 細線化処 理を施すと同時にひび割れ幅の算出の一部を行う。図 7 に 示すように, 細線化処理の過程でひび割れ画素を消去する 際に，消去するひび割れ画素が持つひび割れの輝度值を， 周辺のひび割れ画素に均等に割り当てる。これを細線化処 理が終了するまで繰り返す。最終的な細線化後の画像にお ける各骨格画素には, 周囲の輝度值の総和 $I_{\text {sum }}(x, y)$ が与えら れる。ただし， $I_{\text {sum }}(x, y)$ は輝度值の総和であり，256 階調の グレースケール画像では表現することはできないため, 別 途に 2 次元配列 $S(x, y)$ として保持寸る。従って, 細線化後の 画像 $I(x, y)$ は次のようになる。

$$
I(x, y)=\left\{\begin{array}{cc}
0 & \text { if } \\
255 & \text { structure pixel }
\end{array}\right.
$$

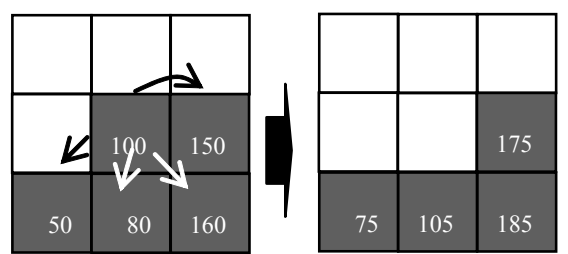

Fig. 7. Calculation of crack brightness.

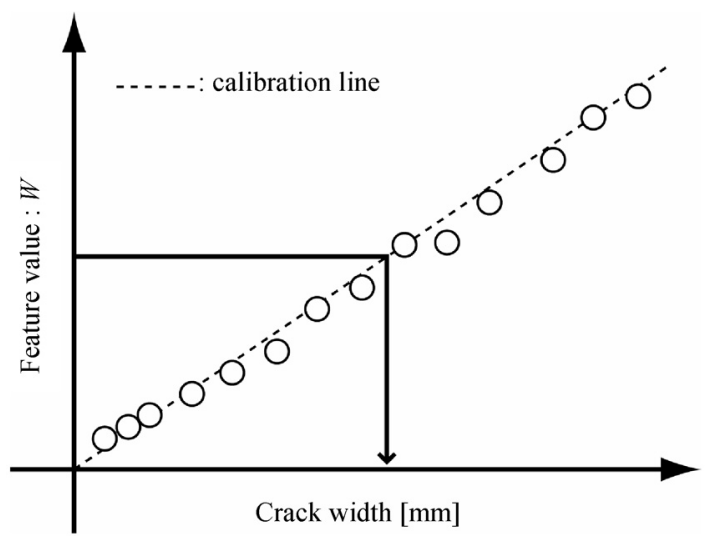

Fig. 8. Measurement of crack width.

次に, ラベリング処理後に, (8)式を用いてラベル毎に特 徵量 $W$ を算出する。ここで, ラベリング処理後の画像 $I(x, y)$ にはラベル番号が与えられているものとする。

$$
W_{i}=\operatorname{med}_{j \in R_{i}}\left(S_{j}(x, y)\right)
$$

ここで, $i$ はラベル番号, $R_{i}$ はラベル内の画素集合, $j$ は $R_{i}$ の画素集合の添え字, $S_{j}(x, y)$ は細線化処理の 過程で算出した総和輝度值とする。 $\operatorname{med}()$ は括弧内 の中央值を算出する関数である。従って，特徵量 $W$ はラベル内の $S_{j}(x, y)$ の中央值で表される。

ここで, 図 2(c)の破線の円で示したコンクリートの気泡と ひび割れが連結し同じラベル番号となる場合に, (8)式では 中央值を用いるため, 外れ值に影響されない特徴量 $W$ の算 出処理が行える。

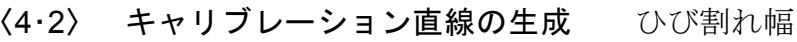
をサブピクセル精度でかつ, 実寸で計測するために, クラ ックスケールを用いてキャリブレーションを行う。クラッ クスケールに記載されている各目盛り $(\mathrm{mm}$ 単位)を横軸, (8)式で算出した特徵量 $W$ を縦軸とし, 2 次元の特徵量空間 を生成する。クラックスケールの目盛り毎に算出した特徵 量 $W$ を用いて, 特徵量空間にプロットすると図 8 のように 表せる。そして, プロット点から最小二乗法で原点を通る ような近似直線を生成すると図 8 の破線のようになる。通 常は切片を考慮して最小二乗法で解析するが，切片が存在 するとひび割れ幅がマイナス值になる場合がある。提案手 法ではシェーディング補正を行っているため, 原点を通過 させることができる。従って，(3)式のようになる。

$y=a x$

ここで, $a$ は近似直線の傾きであり, 最小二乗法で 算出する。また，この近似直線を本論ではキャリ 
ブレーション直線と呼ぶ。

従って，ひび割れ幅の実寸計測は，各ひび割れの特徵量 $W$ を算出し, キャリブレーション直線を表す(9)式の $y$ に代 入することで，ひび割れ幅の実寸值を算出する。

次章の評価実験で提案手法のキャリブレーション直線の 妥当性は確認する。またひび割れが画像上ではコンクリー トの亀裂の影であり, シェーディング補正を行ったとして も，輝度值を用いる場合には，照明による影響は避けられ ない可能性がある。特に, 提案手法では周囲の画素の輝度 值の総和を用いており, 幅が広いほど照明変化による誤差 の総和が高くなると考えられる。従って, 照明による影響 についても次章で検討する。

\section{5. 評価実験}

提案手法の有効性を評価するため，コンクリート表面に クラックスケールを 2 枚写りこませて獲得した画像中の部 分画像を用いて評価実験を行う。評価実験に用いる 3 つの テスト画像を図 9 に示す。画像サイズは, 全体のコンクリ ート表面を撮影した $4064 \times 2704$ [pixels]の画像中の $1600 \times$ 2000 [pixels] の部分画像であり, 1 画素は実寸で約 $0.22 \mathrm{~mm}$ 程 度に相当するものを利用する。各テスト画像の違いは, 照 明の条件が異なる。図 9(a)と(b)は 2 つのクラックスケール に照明が均一に照らされた場合であり，(c)は(b)に対して， 照明は不均一な場合である。クラックスケール A と B にお いて, 目盛り毎に平均輝度值を比較すると, 平均輝度值の 差が(a)と(b)は 5〜 7 程度であるのに対し, (c)の場合は約 15 程度であり，最大で 30 異なる。

計測までの手順は 3 章に基づいて行う。クラックスケー ルを擬似ひび割れとして抽出し，4 章で提案した手法を用い て擬似ひび割れの幅を算出する。

評価の手順は，クラックスケール $A$ で作成したキャリブ レーション直線を用いて, クラックスケール $B$ の幅を測定 する $(A \rightarrow B)$ 。同様に, クラックスケール $B$ で作成したキャ リブレーション直線の場合 $(B \rightarrow A)$ にも同作業を行う。そ して, クラックスケールの各目盛りを正解值とし, 両方の 計測值と正解值との誤差を算出し, 計測精度を評価する。 図 10 に各テスト画像に含まれるクラックスケールを用いて キャリブレーション直線を算出したものを示す。表 1 に各
直線の重相関係数 $R$, 正解值であるクラックスケールの目盛 りとの誤差の絶対值の平均值, その誤差のテスト毎の平均 值を示す。また, 提案手法のクラックスケールの幅の輝度 情報を用いた計測手法と比較を行うため, 計測手法のみ従 来手法 ${ }^{(16)}$ の面積の輝度情報を用いた場合の結果も示す。こ こで, 従来手法を用いる場合のクラックスケールの目盛り の長さを算出する際には, ラベリング処理後の画像におい て, ラベル毎の骨格画素の連結数を長さとして用いた。長 さの規格化の基準值には, 目盛り毎の長さの中で, 最小の 長さを基準值とした。

まず, 表 1 より, 全てのクラックスケールの重相関係数 $R$ が 0.98 以上となり, 提案手法のクラックスケールの目盛り と特徵量 $W$ を用いたキャリブレーション直線の妥当性が確 認できた。

次に, 幅計測の精度については, 照明条件が均一である Test 1 と 2 の場合は, 両結果とも誤差が $0.07 \mathrm{~mm}$ 程度であり, 1 画素が約 $0.22 \mathrm{~mm}$ の解像度であることを考慮すると, 計測 誤差は画素精度の 3 分の 1 以下であり, サブピクセルの精 度範囲に治まる結果となった。Test 3 の場合も誤差が $0.08 \mathrm{~mm}$ 程度であり, サブピクセルの精度範囲であるが, Test 1 と 2 に比べて誤差が大きくなった。また, 従来手法 ${ }^{(16)}$ も全 体の傾向は同様の結果となったが, 各実験の計測精度を比 較すると全ての結果において, 提案手法の方が精度は良い 結果となった。

これらより, 提案手法は輝度值を用いて特徵量を算出し ているため, 照明条件が均一である場合には高精度に計測 することができることが分かる。また，クラックスケール の面積の輝度情報を用いて計測するよりも, 幅の輝度情報 のみで計測したほうが高精度であると言える。

次に照明の影響について考察を行う。図 9(a)と(b)では照 明を均一に設定するために, カメラを挟むように, 拡散光 のハロゲン電球を 2 台設置した。一方, 図 9(c)では, 上部か らの蛍光灯による照明のみを用いた。その結果である図 10 を見ると, (a)と(b)に比べて, (c)の場合は, クラックスケー ルの幅が大きくなるに連れて, 2 つのキャリブレーション直 線の間隔が大きくなっているのが確認できる。これは, 4.2 節で述べたとおり, 幅が広いほど照明変化による誤差の総 和が高くなるからだと考えられる。一方, 幅が狭い $0.1 \mathrm{~mm}$

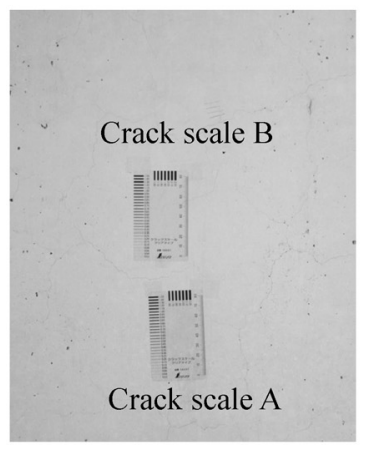

(a) Test image 1

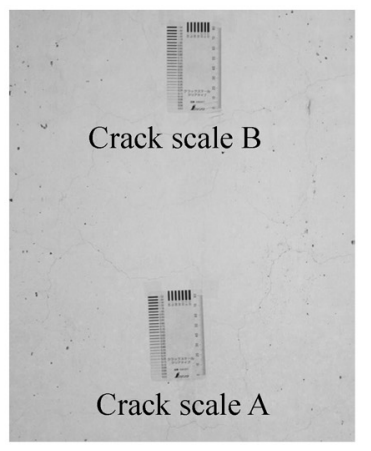

(b) Test image 2

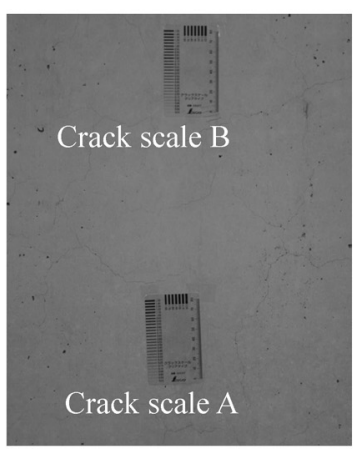

(c) Test image 3

Fig. 9. Test images. 


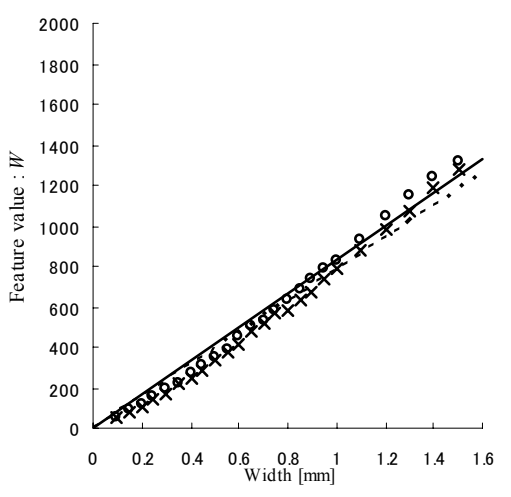

(a) Test image 1

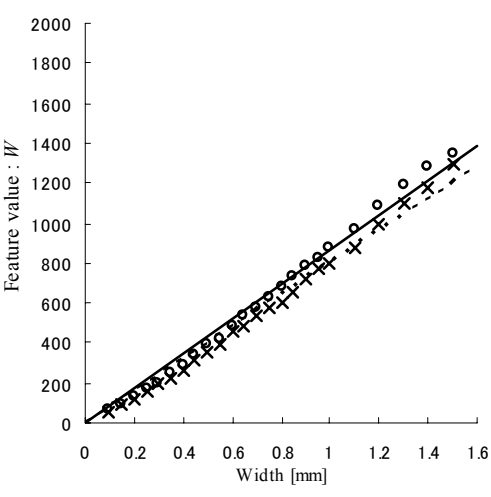

(b) Test image 2

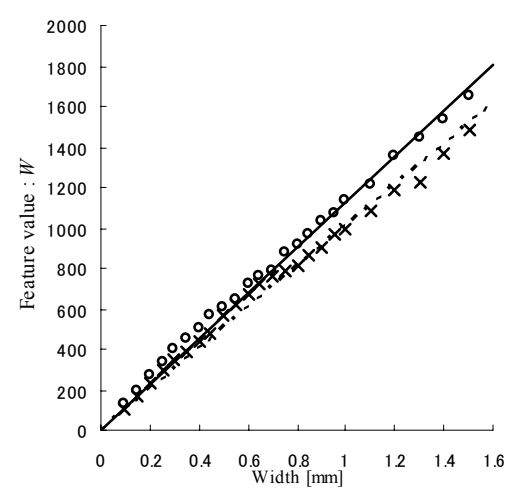

(c) Test image 3

Fig. 10. Calibration lines ( $\mathrm{O}$ : Crack scale A, $\times$ : Crack scale B, - : Calibration line A, - - : : Calibration line B).

Table 1. Evaluation of proposed method.

\begin{tabular}{|c|c|c|c|c|c|c|}
\hline & \multicolumn{2}{|c|}{ Test 1} & \multicolumn{2}{|c|}{ Test 2} & \multicolumn{2}{|c|}{ Test 3} \\
\hline Evaluation criteria & $\mathrm{A} \rightarrow \mathrm{B}$ & $\mathrm{B} \rightarrow \mathrm{A}$ & $\mathrm{A} \rightarrow \mathrm{B}$ & $\mathrm{B} \rightarrow \mathrm{A}$ & $\mathrm{A} \rightarrow \mathrm{B}$ & $\mathrm{B} \rightarrow \mathrm{A}$ \\
\hline$R$ of calibration line & 0.9908 & 0.9893 & 0.9941 & 0.9929 & 0.9962 & 0.9938 \\
\hline Average error $\mathrm{mm}$ & 0.0716 & 0.0622 & 0.0745 & 0.0634 & 0.0655 & 0.1021 \\
\hline Average error per Test $\mathrm{mm}$ & \multicolumn{2}{|c|}{0.0669} & \multicolumn{2}{|c|}{0.0690} & \multicolumn{2}{|c|}{0.0838} \\
\hline Average error ${ }^{(16)} \mathrm{mm}$ & 0.0837 & 0.0728 & 0.0883 & 0.1058 & 0.0922 & 0.1109 \\
\hline Average error per Test ${ }^{(16)} \mathrm{mm}$ & \multicolumn{2}{|c|}{0.0783} & \multicolumn{2}{|c|}{0.0971} & \multicolumn{2}{|c|}{0.1015} \\
\hline
\end{tabular}

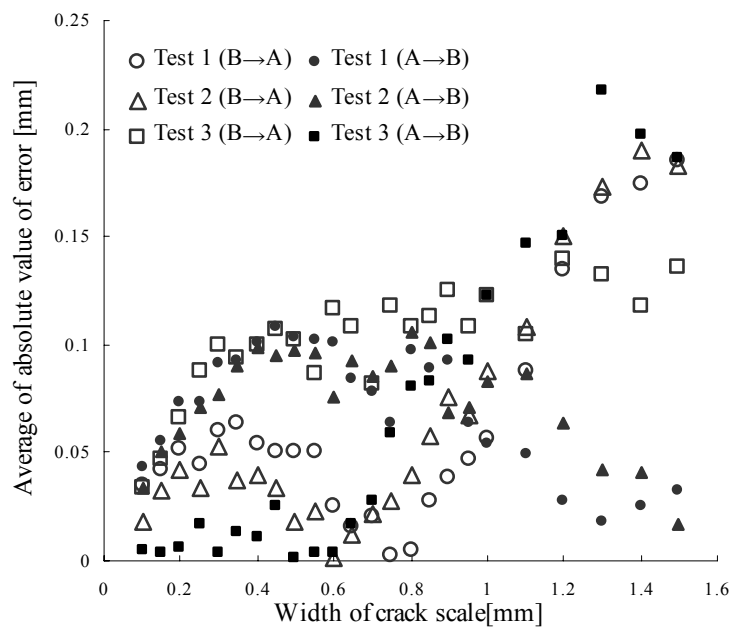

Fig. 11. Distribution of error.

〜 $0.5 \mathrm{~mm}$ 付近では， $1.0 \mathrm{~mm}$ 以上に比べて照明による影響 は小さい。この影響を確認するため，提案手法の結果に対 して, キャリブレーション直線により算出した各スケール の幅の正解值との誤差の絶対值の分布を図 11 に示す。

図 11 より，上述のとおりクラックスケールの幅が広くな るにしたがい，誤差が拡大していることが確認できる。た だし, $0.1 \mathrm{~mm} \sim 0.5 \mathrm{~mm}$ のよう幅の狭い部分に関しては, 約 $0.1 \mathrm{~mm}$ 未満のサブピクセル精度の誤差範囲であることか ら，幅計測の対象が細くサブピクセル精度のひび割れにな らば，照明が不均一であった場合においても提案手法は適 用可能であると考えられる。

\section{6. ひび割れ幅計測の実験}

本章では，提案手法を用いて既設コンクリート構造物の コンクリート表面に存在するひび割れの幅計測の結果につ いて報告する。 5 章で行った提案手法の評価実験の結果を踏 まえて, $0.06 \mathrm{~mm} \sim 0.3 \mathrm{~mm}$ 程度のひび割れ幅が存在するコン クリート表面を撮影対象とした。図 12 に実験で用いる 2 つ のテスト画像を示す。図 12(a)と(b)は全く同じ場所を撮影し たものである。ここで，5章の評価実験では，図 12 のクラ ックスケールの一部を用いたため（図 12(a)：Test image 3,

(b) : Test image 2), 照明条件は同様である。画像サイズは $4064 \times 2704$ [pixels]である。

まず， 3 章の手順に基づき，ひび割れ検出を行う。2 值化 処理では, 図 12(a)及び(b)は同じ閾值で処理を行った。図 12(a)に対してひび割れ検出を行ったものを図 13 に示す。次 にひび割れ幅計測を行う。ひび割れ幅計測を行う際に必要 であるキャリブレーション直線は， 5 章の評価実験で生成し たものを用いる。図 13 に示した $1 \sim 20$ までの番号のひび割 れを対象に,ひび割れ幅計測を行う。提案手法のひび割れ

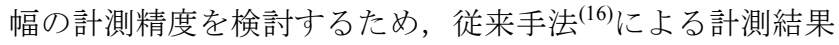
と専門技術者がクラックスケールを用いて行う目視計測と 比較する。今回は, 専門技術者による計測結果を正解值と して利用する。番号ごとのひび割れ幅計測の結果を表 2 に 示し，正解值との誤差の絶対值の平均を表 3 に示す。

まず，撮影対象が $0.06 \mathrm{~mm} \sim 0.3 \mathrm{~mm}$ 程度の細いひび割れ 幅である場合においても, 筆者らのひび割れ検出手法 ${ }^{(8)}$ を用 いることにより, 図 13 に示したようなひび割れのみの画像 


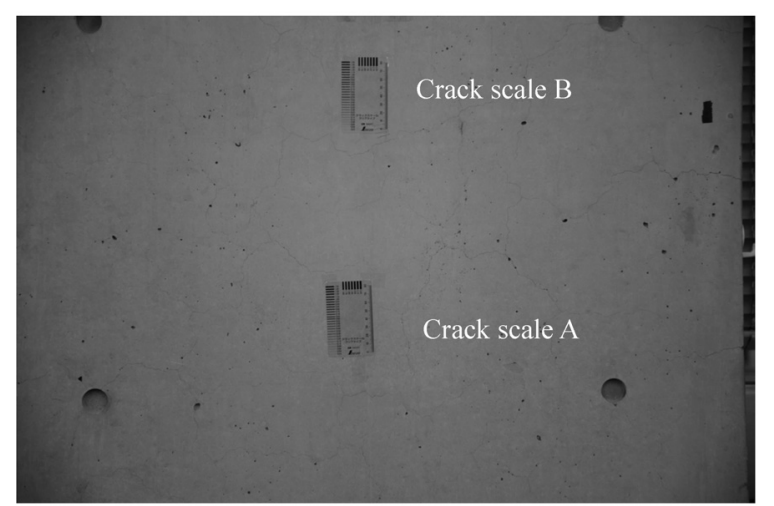

(a) Image 1

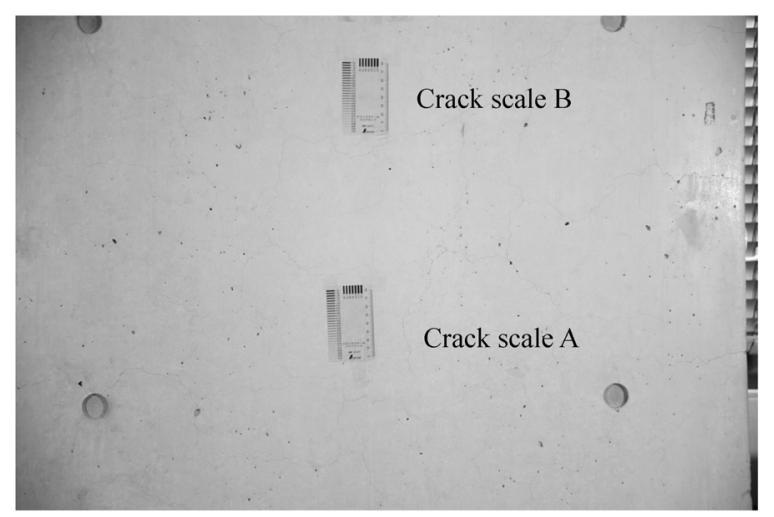

(b) Image 2

Fig. 12. Images of experiment.

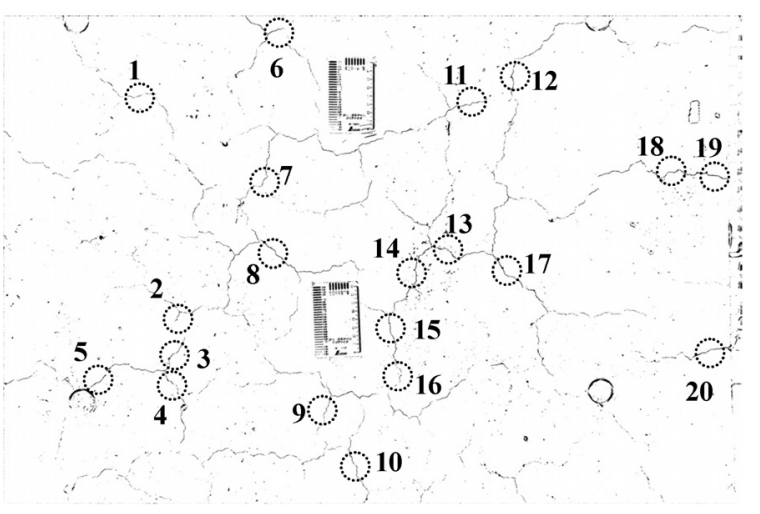

Fig. 13. Crack detection of Image 1.

を取得できることが確認できる。次に，提案手法のひび割 れ幅計測に必要なキャリブレーション直線については，計 測対象がクラックスケールではなく，ひび割れである場合 においても，キャリブレーション直線が A と B のどちらを 用いても同等の幅計測を行えていることが表 2 より確認で きる。表 3 より, 計測精度に関しては, 平均して約 $0.043 \mathrm{~mm}$ となり, サブピクセル精度の誤差範囲を実現した。ここで, 専門技術者が目視で計測を行う場合には $0.1 \mathrm{~mm} \sim 1.0 \mathrm{~mm}$ ま ではクラックスケールの間隔が $0.05 \mathrm{~mm}$ であるため, 提案 手法の数值は許容誤差の範囲内であると言える。

また, Image 1 と Image 2 の場合も同等の計測精度であり, 計測対象のひび割れ幅が $0.06 \mathrm{~mm} \sim 0.3 \mathrm{~mm}$ であることから,
5 章で考察したとおり, ひび割れ幅がサブピクセル精度の細 い場合には, 照明が不均一な場合でも提案手法は有効であ ることが示せた。従来手法の結果は約 $0.055 \mathrm{~mm}$ でほぼ同等 であるが， 5 章の評価実験と同様に提案手法の計測精度が上 回る結果となり, クラックスケールの面積の輝度情報を用 いて計測するよりも，幅の輝度情報のみで計測したほうが 高精度である言える。

\section{7. 実利用の適用範囲}

\section{（1）コンクリート壁面の表面状態について}

実構造物のコンクリートの表面には, 染み, 污れやコン クリートの型枠等が含む場合が考えられる。染みや污れな どの非直線的な特徴は，3 章(2)で示したパーコレーション モデルに基づくひび割れ検出手法 ${ }^{(8)}$ により, ひび割れ検出処 理で抽出されない。このことに関しては，既に染みや污れ 等のノイズのある実構造物の壁面検査に適用する実験を行 っている ${ }^{(9)}$ 。しかし, コンクリートの型枠等の直線的な特徵 は, 筆者らの手法 ${ }^{(8)}$ ではひび割れとして検出するため, ひび 割れではない型枠の幅計測を行ってしまう。コンクリート の型枠は規則的に配置されているため, トップダウン情報 として予め計測の対象から除去する必要がある。

\section{（2）照明について}

照明に関しては, 照明が均一である場合と, 不均一な場 合がある。照明が均一な場合は, ひび割れ幅計測をサブピ クセル精度で計測可能である。また, 照明が不均一である 場合においても, ひび割れが細い場合にはサブピクセル精 度で計測することが可能である。カメラのダイナミックレ ンジに関する定量的な実験は行っていないが, 本手法では ひび割れ部と非ひび割れ部が区別できる程度であればよい と考えられる。

\section{（3）計測対象のひび割れ幅について}

提案手法では, クラックスケールの目盛りを用いたキャ リブレーション直線によりひび割れ幅計測を行うため, 計 測可能な幅には制限がない。ただし，提案手法は，計測す る対象の幅が太くなるに連れて計測精度が減少するため, サブピクセル精度で計測を行う場合には， $0.5 \mathrm{~mm}$ 未満まで が望ましい。

\section{（4）計測対象のコンクリート壁面について}

提案手法は, クラックスケールを画像中に写りこませる ことにより, ひび割れ幅を計測する。従って, 高所の壁面 や天井等でもクラックスケールを設置することが可能であ れば，ひび割れ幅を計測することができる。

\section{8. 結言}

本論文では, 実構造物のコンクリート表面を撮影対象と したひび割れ幅の実寸計測手法について提案した。提案手 法において，ひび割れ検出では，既に実構造物のコンクリ 一ト表面像に適用した筆者らの手法( ${ }^{(8)}$ を用いて, ひび割れ幅 計測可能な画像を生成することができた。次にひび割れ幅 の実寸計測では，人間がクラックスケールを利用してひび 
Table 2. Results of crack width measurement.

\begin{tabular}{|c|c|c|c|c|c|c|c|c|c|}
\hline \multirow{3}{*}{ No. } & \multicolumn{4}{|c|}{ Proposed method $\mathrm{mm}$} & \multicolumn{4}{|c|}{ Previous method $^{(16)} \mathrm{mm}$} & \multirow{3}{*}{$\begin{array}{c}\text { Answer of } \\
\text { Crack Width } \\
\text { mm }\end{array}$} \\
\hline & \multicolumn{2}{|c|}{ Image 1} & \multicolumn{2}{|c|}{ Image 2} & \multicolumn{2}{|c|}{ Image 1} & \multicolumn{2}{|c|}{ Image 2} & \\
\hline & $\mathrm{A} \rightarrow \mathrm{B}$ & $\mathrm{B} \rightarrow \mathrm{A}$ & $\mathrm{A} \rightarrow \mathrm{B}$ & $\mathrm{B} \rightarrow \mathrm{A}$ & $\mathrm{A} \rightarrow \mathrm{B}$ & $\mathrm{B} \rightarrow \mathrm{A}$ & $\mathrm{A} \rightarrow \mathrm{B}$ & $\mathrm{B} \rightarrow \mathrm{A}$ & \\
\hline 1 & 0.0526 & 0.0591 & 0.0526 & 0.0498 & 0.0460 & 0.0575 & 0.0479 & 0.0518 & 0.1 \\
\hline 2 & 0.0767 & 0.0861 & 0.0767 & 0.0677 & 0.0625 & 0.0880 & 0.0757 & 0.0818 & 0.06 \\
\hline 3 & 0.0989 & 0.1110 & 0.0989 & 0.1218 & 0.1138 & 0.0906 & 0.1223 & 0.1322 & 0.2 \\
\hline 4 & 0.0878 & 0.0985 & 0.0878 & 0.0941 & 0.0879 & 0.1432 & 0.0866 & 0.0936 & 0.1 \\
\hline 5 & 0.1263 & 0.1418 & 0.1263 & 0.1356 & 0.1267 & 0.2335 & 0.1003 & 0.1084 & 0.15 \\
\hline 6 & 0.0918 & 0.1031 & 0.0918 & 0.0789 & 0.0728 & 0.0890 & 0.0647 & 0.0700 & 0.25 \\
\hline 7 & 0.0765 & 0.0858 & 0.0765 & 0.0605 & 0.0558 & 0.0807 & 0.0588 & 0.0635 & 0.15 \\
\hline 8 & 0.1146 & 0.1286 & 0.1146 & 0.0912 & 0.0843 & 0.1175 & 0.0885 & 0.0957 & 0.2 \\
\hline 9 & 0.0800 & 0.0898 & 0.0800 & 0.0712 & 0.0665 & 0.0929 & 0.0608 & 0.0657 & 0.08 \\
\hline 10 & 0.0876 & 0.0983 & 0.0876 & 0.0780 & 0.0729 & 0.0935 & 0.0666 & 0.0720 & 0.08 \\
\hline 11 & 0.0721 & 0.0809 & 0.0721 & 0.0431 & 0.0398 & 0.0843 & 0.0429 & 0.0464 & 0.1 \\
\hline 12 & 0.1110 & 0.1246 & 0.1110 & 0.0948 & 0.0876 & 0.1085 & 0.0873 & 0.0944 & 0.15 \\
\hline 13 & 0.0818 & 0.0918 & 0.0818 & 0.0802 & 0.0741 & 0.1127 & 0.1312 & 0.1419 & 0.1 \\
\hline 14 & 0.0809 & 0.0908 & 0.0809 & 0.0970 & 0.0907 & 0.0822 & 0.1102 & 0.1192 & 0.1 \\
\hline 15 & 0.1260 & 0.1414 & 0.1260 & 0.1072 & 0.1001 & 0.1332 & 0.0941 & 0.1017 & 0.15 \\
\hline 16 & 0.0946 & 0.1061 & 0.0946 & 0.0776 & 0.0725 & 0.1087 & 0.0841 & 0.0910 & 0.08 \\
\hline 17 & 0.1046 & 0.1174 & 0.1046 & 0.0885 & 0.0817 & 0.1155 & 0.0731 & 0.0790 & 0.15 \\
\hline 18 & 0.1363 & 0.1529 & 0.1363 & 0.1803 & 0.1685 & 0.1224 & 0.1539 & 0.1664 & 0.2 \\
\hline 19 & 0.2015 & 0.2261 & 0.2015 & 0.2608 & 0.2436 & 0.0830 & 0.2226 & 0.2407 & 0.3 \\
\hline 20 & 0.1491 & 0.1674 & 0.1491 & 0.1292 & 0.1207 & 0.1196 & 0.1131 & 0.1223 & 0.15 \\
\hline
\end{tabular}

Table 3. Results of precision.

\begin{tabular}{|c|c|c|c|c|c|c|c|c|}
\hline & \multicolumn{4}{|c|}{ Proposed method $\mathrm{mm}$} & \multicolumn{3}{c|}{ Previous method ${ }^{(16)} \mathrm{mm}$} \\
\cline { 2 - 9 } & \multicolumn{2}{|c|}{ Image 1 } & \multicolumn{2}{|c|}{ Image 2 } & \multicolumn{2}{c|}{ Image 1 } & \multicolumn{2}{c|}{ Image 2 } \\
\cline { 2 - 9 } & $\mathrm{A} \rightarrow \mathrm{B}$ & $\mathrm{B} \rightarrow \mathrm{A}$ & $\mathrm{A} \rightarrow \mathrm{B}$ & $\mathrm{B} \rightarrow \mathrm{A}$ & $\mathrm{A} \rightarrow \mathrm{B}$ & $\mathrm{B} \rightarrow \mathrm{A}$ & $\mathrm{A} \rightarrow \mathrm{B}$ & $\mathrm{B} \rightarrow \mathrm{A}$ \\
\hline Average error & 0.0439 & 0.0372 & 0.0493 & 0.0429 & 0.0594 & 0.0569 & 0.0544 & 0.0500 \\
\hline Average error per image & \multicolumn{3}{|c|}{0.0405} & \multicolumn{3}{|c|}{0.0461} & \multicolumn{3}{c|}{0.0581} & 0.0522 \\
\hline Average error per method & \multicolumn{4}{|c|}{0.0433} & \multicolumn{5}{c|}{0.0551} \\
\hline
\end{tabular}

割れ幅の計測を行うことに注目し，クラックスケールを画 像中に写りこませ，クラックスケールの目盛り幅毎に，輝 度值を算出することによって, キャリブレーション直線を 生成し, 画像内のひび割れ幅を実寸で計測する手法を提案 した。また，輝度情報は特に照明の条件に影響があると考 えられるため, その影響について評価を行った。評価実験 を通して，提案手法のキャリブレーション直線を用いたひ び割れ幅の計測手法の有効性を示すことができ，従来手法 よりも計測精度が改善された。照明条件に関しては, 計測 する対象の幅が太くなるに連れて計測精度が減少するが, 計測対象の幅が細い場合には，照明条件が均一でない場合 においても, サブピクセル精度である $0.1 \mathrm{~mm}$ 未満で計測で きることを確認した。このような考察により，0.06 mm 0.3 $\mathrm{mm}$ 程度の細いひび割れ幅が存在する既設コンクリート構 造物の壁面像を用いて，ひび割れ幅の実寸計測を行った。 ひび割れ幅の計測精度は約 $0.05 \mathrm{~mm}$ 未満を実現し, 計測対象 が細いひび割れに対しては提案手法を適用することが可能 であることが確認できた。最後に一連の実験の考察を整理 し, 実構造物に対する本手法の適用範囲についてまとめた。 電力施設のようなコンクリート構造物は, とりわけ電力需 要の停滞に伴い, 新規建設の緊急性がなくなり, 専ら既設
物の維持管理が重要視されており,ひび割れ検査も必要と されている。このような施設は, 乾燥収縮が原因によるひ び割れ幅が細いものが多いため, 提案手法が適用できると 考えられる。定期的に検査することが必要であるため, 人 的な作業では非効率であり, 画像検査の必要性は十分にあ る。また一般の検査対象の壁面は規模が広大であり, 高所 にあるなど, 人間では検査が困難であるため, 壁面撮像口 ボット ${ }^{(20)(21)}$ の導入が求められている。壁面撮像ロボットを 開発することにより, クラックスケールの設置や照明を均 一に設定し撮影することも可能であると考えられ, 本研究 の適用が期待できる。

今後の課題としては, クラックスケールをユーザが指定 することによりひび割れ幅の計測を行っており, 提案手法 は半自動的な処理である。テンプレートマッチング等を用 いることにより, 画像中からクラックスケールを認識し, 自動的なひび割れ計測のシステムを構築することを考えて いる。さらに, 筆者らも壁面撮像ロボットを製作し, ロボ ットを用いたひび割れ計測を行うことを計画している。

本研究を進める際にご協力を頂いた株式会社大林組, 株 式会社大林組 田中秀樹氏に感謝いたします。

なお, 本研究の一部は, 文部科学省 21 世紀 COE プログ 
ラム（研究拠点形成費補助金）「超高齢社会における人と口 ボット技術の共生」の研究助成, 文部科学省科学技術振興 調整費戦略的研究拠点プログラム「先端科学と健康医療の 融合研究拠点の形成」の研究助成, 早稲田大学 WABOT-HOUSE 研究所(岐阜県)の支援を受けて行われた。 (平成 18 年 7 月 31 日受付, 平成 18 年 12 月 15 日再受付)

\section{文献}

（1）日本建築学会: 「鉄筋コンクリート造建築物の収縮ひび割れーメカニ ズムと対策技術の現状一」，日本建築学会 (2003)

（2）日本コンクリート工学協会：「コンクリートのひび割れ調査，補修・ 補強指針一2003-」, 日本コンクリート工学協会 (2003)

（3）河村 圭・宮本文穂・中村秀明・佐藤 亮:「対話型遺伝的アルゴリ ズムによるデジタル画像からのひび割れ抽出」, 土木学会論文集, 742/VI-60, pp.115-131 (2003)

(4) F. Roli : "Measure of Texture Anisotropy for Crack Detection on Textured Surfaces", ELECTRONICS LETTERS, Vol.32, No.14, pp.1274-1275 (1996)

（5）佐藤仁人・濱村誠彦・中山和美・源間敏雄・溝口信夫 :「デジタル画 像によるコンクリートクラック検出システムの開発」, 日本建築学会 技術報告集, 17, pp.485-488 (2003)

(6) I. Abdel-Qader, O. Abudayyeh, and M. E. Kelly : "Analysis of Edge Detection Techniques for Crack Identification in Bridges", Journal of Computing in Civil Engineering, Vol.17, No.3, pp.255-263 (2003)

( 7 ) T. C. Hutchinson and Z. Chen : "Improved Image Analysis for Evaluating Concrete Damage", Journal of Computing in Civil Engineering, Vol.20, No.3, pp.210-216 (2006)

(8) T. Yamaguchi and S. Hashimoto : "Image Processing Based on Percolation Model", IEICE Trans. Info. and Sys., Vol.E89-D, No.7, pp.2044-2052 (2006)

(9) T. Yamaguchi and S. Hashimoto : "Automated crack detection for concrete surface image using percolation model and edge information", Proc. of IECON2006, pp.3355-360 (2006)

(10) P. M. Dare, H. B. Hanley, C. S. Fraser, B. Riedel, and W. Niemeier : "An Operational Application of Automatic Feature Extraction: the Measurement of Cracks in Concrete Structures", Photogrammetric Record, Vol.17, No.99, pp.453-464 (2002)

(11) L. C. Chen, H. H. Jan, and C. W. Huang: "Mensuration of concrete cracks using digitized close-range photographs", Proc. of 22nd Asian Conference on Remote Sensing, Vol.2, pp.1248-1253 (2001)

(12) L. C. Chen, Y. C. Shao, H. H. Jan, C. W. Huang, and Y. M. Tien : "Measuring System for Cracks in Concrete Using Multitemporal Images", Journal of Surveying Engineering, Vol.132, No.2, pp.77-82 (2006)
(13) H. G. Sohn, Y. M. Lim, K. H. Yun, and G. H. Kim : "Monitoring Crack Changes in Concrete Structures", Computer-Aided Civil and Infrastructure Engineering, Vol.20, No.1, pp.52-61 (2005)

(14) 佐野 浩・大澤 廣・後藤和夫・堀内宏信 :「マーカーとデジタルカ メラを利用したひび割れ計測システムの開発」, 土と基磾, 52,6 , pp.22-24 (2004)

(15) G. De Schutter : "Advanced Monitoring of Cracked Structures Using Video Microscope and Automated Image Analysis", NDT \& $E$ International, Vol.35, No.4,pp.209-212 (2002)

(16) A. Ito, Y. Aoki, and S. Hashimoto : "Accurate extraction and measurement of fine cracks from concrete block surface image", Proc. of IECON2002, pp.77-82 (2002)

(17) D. Stauffer : Introduction To Percolation Theory, 2nd Edition, CRC press (1994)

(18) C. J. Hilditch : "Linear Skeletons from Square Cupboards", Machine Intelligence 4, Edinburgh Univ. Press, pp.403-420 (1969)

(19) 高木幹雄・下田陽久：「画像解析ハンドブック」, 東京大学出版会 (1991)

(20) 広瀬茂男・長久保晶彦: 「歩行型壁面移動ロボット」, 日本ロボット 学会誌, 10, 5, 575-580 (1992)

(21) S. Kim, A. T. Asbeck, M. R. Cutkosky, and W. R. Provancher : "SpinybotII: climbing hard walls with compliant microspines", Proc. of ICAR05, pp.601-696 (2005)

山口友之（非会員） 1979 年 12 月 5 日生。 2002 年 3 月早

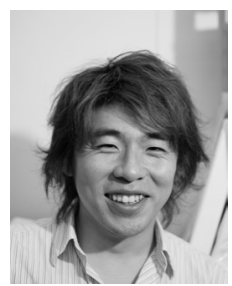
稲田大学理工学部機械工学科卒業。2004 年同大 学大学院修士課程修了。現在, 早稲田大学大学 院博士課程在学, 早稲田大学理工学術院客員研 究助手。画像処理, 画像認識の研究に従事。電 子情報通信学会, 情報処理学会, 日本非破壊検 查協会各会員。

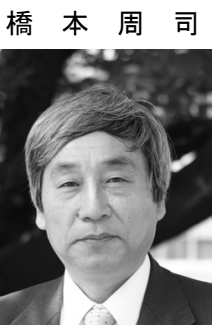

（正員） 1948 年 1 月 27 日生。1970 年 3 月早 稲田大学理工学部応用物理学科卒業。1977 年同 大学大学院博士課程修了 (工学博士)。現在, 早稲田大学理工学術院教授。確率過程の応用, 画像処理，ヒューマンインターフェース，人間 共存ロボット, 音楽情報処理, ニューラルネッ トワーク, 感性情報処理の研究に従事。電気学 会, 情報処理学会, 画像電子学会, 日本顔学会, 日本ロボット学会, 計測自動制御学会, IEEE, ICMA 各会員。 